\title{
Penerapan Pendekatan Open-Ended untuk Meningkatkan Kemampuan Berpikir Kritis Siswa Pada Materi Aljabar Kelas VIII SMP Negeri 10 Pemangkat
}

\author{
Ayu Novia Sari ${ }^{1)}$, Rika Wahyuni ${ }^{2)}$, Rosmaiyadi $^{3)}$ \\ 1) Prodi Pendidikan Matematika STKIP Singkawang, Kalimantan Barat,Indonesia \\ E-mail:ayunovia25@gmail.com \\ ${ }^{2)}$ Prodi Pendidikan Matematika STKIP Singkawang, Kalimantan Barat,Indonesia \\ E-mail:rikawahyuni142@gmail.com \\ ${ }^{3)}$ Prodi Pendidikan Matematika STKIP Singkawang, Kalimantan Barat,Indonesia \\ E-mail:rosmaiyadialong@gmail.com
}

\begin{abstract}
Abstrak. Tujuan penelitian ini untuk mengetahui Penerapan pendekatan pembelajaran Open-Ended dalam meningkatkan kemampuan berpikir kritis siswa pada materi aljabar. Penelitian dilaksanakan di SMP Negeri 01 Pemangkat. Jenis penelitian ini yang digunakan kuantitatif, bentuk penelitian yang digunakan desain Quasi eksperimental dengan bentuk Nonequivalent Control Group. Populasi penelitian adalah siswa kelas VIII yang terdiri dari lima kelas. Sampel penelitian diambil menggunakan purposivesampling maka di dapat kelas VIIIC dengan jumlah 22 siswa sebagai kelas eksperimen dan kelas VIIIE dengan jumlah 22 siswa sebagai kelas kontol. Pengambilan data menggunakan instrument berupa tes uraian yang disesuaikan dengan karakteristik soal kemampuan berpikir kritis matematis dan telah diuji mengunakan validitas, reliabilitas, daya pembeda, dan tingkat kesukaran. Hasil perhitungan kemampuan berpikir kritis siswa pada kelas eksperimen ditunjukan dengan nilai rata rata Post test sebesar 76,5 sedangkan pada kelas control ditunjukan dengan rata rata post test sebesar 69,8 hasil dari uji $\mathrm{N}$-Gain sebesar 0,60 dengan kriteria sedang. Aktivitas yang dilakukan ada peningkatan dari pertemuan pertama yaitu $92,86 \%$ dan pertemuan kedua $93,81 \%$. Dari beberapa hasil perhitungan diatas dapat disimpulkan bahwa Penerapan pendekatan Open-Ended dapat meningkatkan kemampuan berpikir kritis siswa. Peningkatan kemampuan berpikir kritis matematis siswa yang diajarkan dengan Penerapan Pendekatan Open-Ended lebih baik. Keterlaksanaan yang dilakukan ada peningkatan dari pertemuan pertama yaitu 80,27 $\%$ dan pertemuan kedua 85,55 \%. Dari beberapa hasil perhitungan diatas dapat disimpulkan bahwa Penerapan Pendekatan Open-Ended dapat meningkatkan kemampuan berpikir kritis siswa. Peningkatan kemampuan berpikir kritis matematis siswa yang diajarkan dengan Penerapan Pendekatan Open-Ended lebih baik.
\end{abstract}

Kata Kunci: Penerapan Pendekatan Open-Ended, Kemampuan Berpikir Kritis Siswa

\section{PENDAHULUAN}

Matematika merupakan ilmu yang mendasari perkembangan teknologi modern, mempunyai peranan penting dalam berbagai disiplin ilmu dan memajukan daya pikir manusia. Untuk menciptakan teknologi dimasa mendatang sangat diperlukan penguasaan sejak dini. Penguasaan terhadap bidang studi matematika merupakan suatu kewajiban, karena matematika sebagai pintu masuk menguasai sains dan teknologi yang berkembang pesat. Dengan belajar matematika orang dapat mngembangkan kemampuan berpikir secara matematis, logis, kritis dan kreatif yang sungguh dibutuhkan dalam kehidupan. Oleh karena itu matematika merupakan satu diantara ilmu dasar yang perlu diajarkan disekolah.

Sesuai dengan tujuan umum pembelajaran matematika yang dirumuskan oleh [1] bahwa terdapat lima kemampuan dasar matematika yang merupakan standar proses bermatematika satu diantaranya adalah berpikir kritis. Saat ini, pemerintah menerapkan Kurikulum Tingkat Satuan Pendidikan (KTSP), dijelaskan satu diantaranya tujuan pembelajaran matematika adalah agar peserta didik memiliki kemampuan berpikir kritis, merancang model matematika, menyelesaikan model dan menafsirkan solusi yang 


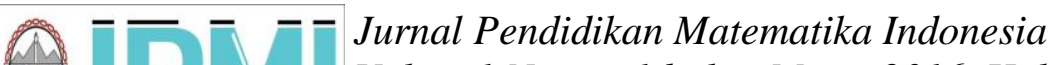

diperoleh. Tujuan tersebut menempatkan berpikir kritis menjadi bagian dari kurikulum matematika yang penting. Dalam proses pembelajaran maupun penyelesaian masalah, siswa dapat memperoleh pengalaman menggunakan pengetahuan serta keterampilan yang sudah dimiliki. Pengalaman inilah yang kemudian melatih daya pikir siswa menjadi logis, analitis, sistematis, kritis dan kreatif dalam menghadapi persoalan.

Berdasarkan penelitian yang dilakukan oleh [2] yang menyatakan bahwa kemampuan berpikir kritis siswa cukup rendah disalah satu SMA Negeri 1 Sukonarjo, yaitu rata-rata hanya memperoleh skor 45 dari 100, sehingga sangat mempengaruhi tercapainya tujuan pembelajaran matematika di sekolah tersebut.

Kemampuan berpikir kritis siswa secara umum dapat diukur dengan beberapa indikator. Secara umum indikator tersebut diantaranya adalah (1) Mengumpulkan dan menyusun informasi yang diperlukan (2) Menemukan cara-cara yang dapat dipakai untuk menangani masalah menganalisis data (4) Menarik kesimpulankesimpulan dan kesamaan-kesamaan yang diperlukan.

Peneliti melakukan prariset dengan memberikan tes uraian menggunakan indikator kemampuan berpikir kritis siswa. Prariset yang dilakukan di SMP Negeri 01 Pemangkat untuk mengetahui kemampuan awal tentang kemampuan berpikir kritis siswa. Soal prariset yang diberikan 1 soal dalam bentuk essay sesuai dengan indikator kemampuan berpikir kritis siswa. Dari hasil prariset tersebut dapat dinyatakan bahwa kemampuan berpikir kritis siswa di SMP Negeri 01 Pemangkat masih rendah.

Berdasarkan hasil wawancara peneliti dengan guru matematika di SMP Negeri 01 Pemangkat masalah yang terjadi dikelas adalah aktivitas siswa kurang dalam mengikuti pembelajaran matematika. Dari keterangan guru matematika SMP Negeri 01 Pemangkat, untuk materi aljabar aktivitas siswa masih tergolong rendah. Hal tersebut berpengaruh pada nilai ulangan harian siswa tahun ajaran lalu yang telah mempelajari materi aljabar tidak mencapai KKM yaitu 70. Padahal guru yang mengajar sudah berpengalaman dan sesuai dengan bidangnya. Tidak hanya terpaku kepada buku panduan yang digunakan dalam pengajaran sudah sesuai dengan standar yang ditentukan dari Dinas Pendidikan. Begitu juga siswa sudah dibantu dengan buku panduan LKS.

Pada tahun ajaran 2015/1016 materi aljabar diajarkan dengan pembelajaran konvensional yaitu metode ceramah dan melakukan kegiatan pembelajaran hanya berdasarkan apa yang diajarkan guru saja. Hanya beberapa siswa yang bertanya atau menanggapi pertanyaan atau pernyataan guru. Oleh karena itu, peneliti ingin menerapkan pendekatan Open-Ended sebagai alternatif pembelajaran yang dapat memacu aktivitas siswa serta dapat mengembangkan kemampuan berpikir kritis siswa.

Pemilihan model pembelajaran yang tepat merupakan bagian yang penting bagi guru sebelum memberikan pelajaran dikelas. Zuldfrial dalam [3] menyatakan bahwa pembelajaran yang tepat dan lebih mengaktifkan siswa adalah pembelajaran berkelompok. Tujuan utama pembelajaran berkelompok adalah agar anak dapat bersosialisasi dan bekerjasama. Suliswa [4] menyatakan bahwa belajar kelompok dapat melatih dan membiasakan siswa saling berbagi pengetahuan dan pengalaman merupakan bagian dari komunikasi. Oleh karena itu, pembelajaran kelompok yang bisa melatih kemampuan berpikir kritis siswa merupakan solusi yang tepat dalam mengurangi pembelajaran yang hanya berpusat kepada guru.

Pendekatan pembelajaran Open-Ended merupakan pendekatan pembelajaran tipe kooperatif yang dapat melatih kemampuan berpikir kritis siswa. Pendekatan Open-Ended merupakan pendekatan pembelajaran yang membangun kegiatan interasi antara matematika dan siswa sehingga mengundang siswa untuk menjawab permasalahan dengan cara mereka sendiri (Sutikno, 2013 :114). Menurut [5] pembelajaran terbuka atau sering dikenal istilah pendekatan Open-Ended merupakan proses pembelajaran yang didalamnya tujuan dan keinginan individu atau siswa dibangun dan dicapai secara terbuka.

Penggunaan pendekatan pembelajaran OpenEnded dalam meningkatkan keaktifan belajar siswa ini dirasakan cukup efektif, karena siswa 
akan terlatih untuk mengemukakan gagasan dan perasaan secara kreatif dan kritis. Serta mampu menemukan dan menggunakan kemampuan analitis dan imajinatif yang ada dalam dirinya untuk menghadapi berbagai persoalan yang muncul dalam kehidupan sehari-hari. Pada materi aljabar ini peneliti membahas operasi aljabar.

Penelitian yang dilakukan oleh [6] menunjukkan bahwa pembelajaran dengan pendekatan OpenEnded pada materi Statistika dapat meningkatkan kemampuan berpikir kritis siswa. Hal ini di lihat dari hasil sebelum tindakan diberikan, pada pemberian tes awal dari 22 siswa hanya sebanyak 7 siswa (35\%) yang mencapai nilai 65 dengan nilai rata-rata kelas 56,65. Setelah diberikan tindakan I, dari 22 siswa sebanyak 10 siswa (50\%) mencapai nilai 65 dengan nilai rata-rata kelas 72,9. Dari analisis data Tes kemampuan berpikir kritis diperoleh bahwa dari 22 siswa terdapat 18 siswa $(90 \%)$ yang mencapai nilai 65 dengan nilai ratarata kelas 79,95.

Aljabar merupakan bagian dari materi matematika SMP kelas VIII semester ganjil, materi Aljabar merupakan materi yang sarat akan soal-soal cerita yang berkaitan dengan kehidupan sehari-hari. materi aljabar dipilih atas pertimbangan bahwa soal cerita yang disajikan dalam buku teks kurang beragam sehingga terkesan kurang memperhatikan kreatif siswa. hal ini berarti materi aljabar harus benar-benar dipahami oleh siswa agar mereka mampu dan terampil dalam mengaplikasikan/memanfaatkan dalam kehidupan sehari-hari.

Berdasarkan uraian diatas penulis tertarik untuk menerapkan pendekatan Open-Ended untuk meningkatkan kemampuan berpikir kritis siswa pada materi aljabar kelas VIII SMP Negeri 01 Pemangkat, dengan menerapkan pendekatan ini diharapkan dapat meningkatkan kemampuan berpikir kritis siswa terhadap pembelajaran matematika.

\section{METODE}

Metode yang digunakan dalam penelitian ini adalah penelitian eksperimen. Bentuk penelitian yang digunakan dalam penelitian ini adalah Nonequivalent Control Group dengan desain penelitian yaitu Quasieksperimental. Populasi dalam penelitian ini adalah seluruh siswa kelas VIII SMP Negeri 01 Pemangkat yang terdiri dari lima kelas. Teknik pengambilan sampel yang digunakan dalam penelitian ini adalah sampling purposive. Sampel dalam penelitian ini adalah kelas eksperimen VIIIC dan kelas kontrol VIIIE SMP Negeri 01 Pemangkat.

Teknik pengumpulan data dalam penelitian ini adalah teknik tes kemampuan berpikir kritis, teknik observasi dan teknik keterlaksanaan. Instrumen pengumpulan data dalam penelitian ini yaitu: a) teknik pengukuran lembar keterlaksanaan pembelajaran; b) tes kemampuan berpikir kritis dalam bentuk essay; c) lembar observasi aktivitas.

Teknik analisis data dalam penelitian ini adalah sebagai berikut: (a) untuk mengetahui sub masalah 1, yaitu mengetahui perbedaan peningkatan kemampuan berpikir kritis siswa yang signifikan antara yang menggunakan pendekatan OpenEnded dan pembelajaran konvensional maka menggunakan $\mathrm{N}$-Gain; (b) untuk menjawab sub masalah 2 yaitu untuk mengetahui keterlaksanaan penerapan pendekatan Open-Ended untuk meningkatkan kemampuan berpikir kritis siswa pada materi aljabar kelas VIII SMP Negeri 01 Pemangkat menggunakan lembar keterlaksanaan pembelajaran; (c) untuk menjawab sub masalah 3 yaitu untuk mengetahui aktivitas belajar siswa terhadap penerapan pendekatan Open-Ended untuk meningkatkan kemampuan berpikir kritis siswa pada materi aljabar kelas VIII SMP Negeri 01 Pemangkat, maka dihitung berdasarkan persentase aktivitas siswa pada lembar observasi.

\section{HASIL DAN PEMBAHASAN}

HASIL

Hasil penelitian ini diperoleh dari beberapa data yang telah dianalisis. Adapun hasil yang diperoleh dari penelitian ini yaitu, hasil tes kemampuan berpikir kritis siswa pada pendekatan Open-Ended, hasil analisis lembar keterlaksaan pembelajaran siswa terhadapan pendekatan Open-Ended, dan hasil observasi aktivitas siswa menggunakan pendekatan Open-Ended. Hasil tes kemampuan berpikir kritis siswa diperoleh dari hasil perhitungan nilai $N$-Gain. Adapun hasil perhitungan nilai $\mathrm{N}$-Gain siswa kelas eksperimen 


\section{- JPMI}

Jurnal Pendidikan Matematika Indonesia

Volum 1 Nomor 1 bulan Maret 2016. Halaman 20-24

p-ISSN: 2477-5967 e-ISSN: 2477-8443 dan kelas kontrol disajikan pada Tabel 1 sebagai berikut.

TABEL 1

REKAPITULASI HASIL $N$-GAINKELAS EKSPERIMEN DAN KELAS KONTROL

\begin{tabular}{lcc}
\hline Keterangan & Kelas Eksperimen & Kelas Kontrol \\
\hline Rata-Rata & 0,60 & 0,42 \\
Standar Deviasi & 0,12 & 0,10 \\
\hline
\end{tabular}

Secara deskripsi terlihat data skor $N$-Gain kelompok kelas eksperimen dan kelas kontrol tidak sama. Maka dari itu untuk selanjutnya akan dilakukan uji perbedaan dua rerata. Selanjutnya dilakukan uji perbedaan rata-rata skor $\mathrm{N}$-Gain kleas eksperimen dan kelas kontrol, namun sebelumnya rata-rata skor $\mathrm{N}$-Gain kelas ekperimen dan kelas kontrol dilakukan uji normalitas dan homogenitas varian data. Adapun rekapitulasi hasil uji normalitas data $N$-Gain untuk kelas eksperimen dan kontrol, dapat dilihat pad tabel 2 berikut.

TABEL 2

REKAPITULASI UJI NORMALITAS DATA $N$-GAIN

\begin{tabular}{lcc}
\hline & Kelas Eksperimen & Kelas Kontrol \\
\hline$x^{2}$ hitung & 0,96 & 0,67 \\
$x^{2}$ tabel & 1,9 & 1,9 \\
Keterangan & Normal & Normal \\
\hline
\end{tabular}

Pada Tabel 2 diatas, terlihat bahwa $\mathrm{x}^{2}$ hitung kelas eksperimen 0,96 dengan $\mathrm{x}^{2}$ tabel 1,9 diketahui $1,9>0,96$, maka dapat disimpulkan bahwa data $\mathrm{N}$-Gain kelas eksperimen berdistribusi normal. Untuk kelas kontrol nilai $\mathrm{x}^{2}$ hitung 0,67 dengan $\mathrm{x}^{2}$ tabel 1,9 diketahui 1,9>0,67, maka dapat disimpulkan bahwa data $N$-Gain kelas kontrol berdistribusi normal. Setelah dilakukan pengujian normalitas terhadap $N$-Gain kelas eksperimen dan kelas kontrol selanjutnya dilakukan uji homogenitas variansinya. Adapun rekapitulasi hasil $\mathrm{N}$-Gain varian kelas eksperimen dan kelas kontrol dapat dilihat pada Tabel 3 sebagai berikut

TABEL 3

REKAPITULASI HASIL $N$-GAIN KELAS EKSPERIMEN DAN KELAS KONTROL

\begin{tabular}{lcc}
\hline & Kelas Eksperimen & Kelas Kontrol \\
\hline Varian & 12,62 & 8,53 \\
$F_{\text {hitung }}$ & & \\
$F_{\text {tabel }}$ & 1,04 & \\
\hline
\end{tabular}

Berdasarkan Tabel 3 terlihat bahwa varian kelas eksperimen adalah 12,62 dan varian kelas kontrol adalah 8,53 sehingga diperoleh Fhitung 1,04 dan
Ftabel 2,12, maka dapat disimpulkan bahwa Fhitung < Ftabel Hal ini berarti varian kedua data $\mathrm{N}$-Gain adalah homogen.

Keterlaksanaan siswa diperoleh setelah kegiatan pembelajaran menggunakan pendekatan OpenEnded. Pendekatan pembelajaran dikatakan berpengaruh terhadap keterlaksanaan jika rata-rata keterlaksanaan siswa berada pada kategori baik atau sangat baik. Adapun rekapitulasi hasil lembar keterlaksanaan siswa dapat dilihat pada Tabel 4 sebagai berikut.

TABEL 4

REKAPITULASI HASIL KETERLAKSANAAN SISWA

\begin{tabular}{lc}
\hline Keterangan & Skor \\
\hline Rata-Rata & 63 \\
Kriteria & Baik \\
\hline
\end{tabular}

Berdasarkan Tabel 4 dan kriteria diatas diketahui bahwa rata-rataketerlaksanaan siswa 63, dengan kriteria baik. Maka dapat disimpulkan bahwa terdapat pengaruh pendekatan Open-Ended terhadap keterlaksanaan siswa.

Observasi yang dilakukan dalam penelitian ini adalah untuk mengetahui pengaruh penerapan pendekatan Open-Ended terhadap aktivitas siswa. Observasi dilakukan dengan menggunakan lembar observasi yang telah divalidasi oleh ahli. Adapun rekapitulasi data hasil observasi pada pertemuan pertama dan kedua dapat dilihat pada Tabel 5 sebagai berikut.

TABEL 5

REKAPITULASI HASIL OBSERVASI AKTIVITAS SISWA

\begin{tabular}{lcc}
\hline & $\begin{array}{c}\text { Persentase Aktivitas } \\
\text { Pertemuan 1 }\end{array}$ & $\begin{array}{c}\text { Persentase Aktivitas } \\
\text { Pertemuan 2 }\end{array}$ \\
\hline $\begin{array}{l}\text { Persentase } \\
\text { Total } \\
\text { Kriteria }\end{array}$ & $85,76 \%$ & $90,65 \%$ \\
\hline
\end{tabular}

Berdasarkan Tabel 5 dan kriteria di atas diperoleh persentase aktivitas siswa secara keseluruhan pada pertemuan pertama adalah $85,76 \%$ dengan kriterian sangat aktif, dan persentase aktivitas siswa secara keseluruhan pada pertemuan kedua adalah 90,65\% dengan kriteria sangat aktif. Karena persentase aktivitas siswa pada kedua pertemuan adalah sangat aktif, maka dapat disimpulkan bahwa terdapat penerapan pendekatan Open-Ended terhadap aktivitas siswa. Sejalan dengan hal tersebut penelitian yang dilakukan oleh Budiarjo (2011:17) menunjukkan 


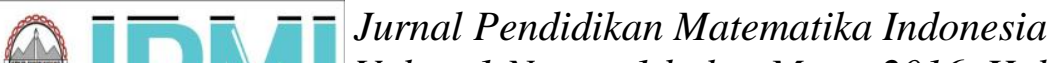

bahwa aktivitas siswa meningkat setelah diterapkan pendekatan Open-Ended dengan 3 siklus. Hal ini berarti pendekatan pembelajaran Open-Ended efektif untuk meningkatkan aktivitas belajar siswa.

\section{KESIMPULAN DAN SARAN}

\section{KESIMPULAN}

Berdasarkan hasil analisis data penelitian, secara umum dapat disimpulkan bahwa terdapat penerapan pendekatan Open-Ended terhadap kemampuan berpikir kritis siswa pada materi aljabar kelas VIII SMP Negeri 01 Pemangkat. Hal ini ditunjukkan oleh sub masalah yang telah terjawab sebagai berikut.

a. Terdapat perbedaan peningkatan kemampuan berpikir kritis siswa yang signifikan antara kelas eksperimen dan kelas kontrol pada materi Aljabar kelas VIII SMP Negeri 01 Pemangkat.

b. Keterlaksanaan pembelajaran matematika dengan menggunakan pendekatan pembelajaran Open-Ended memenuhi kriteria baik pada materi aljabar di kelas VIII SMP Negeri 01 Pemangkat.

c. Aktivitas belajar siswa setelah diberikan penerapan pembelajaran Open-Ended memenuhi kriteria sangat aktif pada materi aljabar di kelas VIII SMP Negeri 01 Pemangkat.

SARAN

Berdasarkan hasil penelitian, saran dalam penelitian ini adalah sebagai berikut.

a. Bagi siswa untuk menambah semangat untuk lebih aktif dalam belajar, berpikir positif bahwa matematika bukanlah pelajaran yang sulit dan berusaha untuk menyenangi matematika.

b. Bagi guru mata pelajaran matematika dapat menjadikan penerapan pembelajaran OpenEnded sebagai alternatif model belajar yang relevan selain pembelajaran langsung sehingga dapat membantu siswa dalam menyelesaikan soal-soal yang berkaitan dengan kemampuan berpikir kritis siswa khususnya materi aljabar.

c. Bagi peneliti, penelitian ini sangat bermanfaat dalam menambah wawasan dan ilmu pengetahuan untuk bekal masa depan sehingga menjadi lebih baik lagi, karena melalui penelitian ini peneliti mendapatkan pengalaman mengenai model pembelajaran yang baik.

d. Bagi peneliti selanjutnya yang ingin meneliti tentang penerapan pembelajaran Open-Ended, sebaiknya mengadakan penelitian lebih mendalam mengenai pengelolaan kelas dan mekanisme dalam penerapan pembelajaran Open-Ended untuk meningkatkan kemampuan berpikir kritis, aktivitas, dan keterlaksanaan pembelajaran siswa pada mata pelajaran matematika.

Demikian kesimpulan dan saran dari peneliti. Semoga dikemudian hari skripsi ini dapat bermanfaat bagi pembaca, terutama bagi saya calon pendidik yang akan menjalankan profesi sebagai pendidik dalam rangka meningkatkan mutu pendidikan.

\section{UCAPAN TERIMA KASIH}

Penulis mengucapkan terima kasih kepada dosen pembimbing yaitu Rika Wahyuni, S.Si., M.Pd. selaku dosen pembimbing I dan Rosmaiyadi,M.Pd. selaku dosen pembimbing II yang telah membimbing dan mengarahkan penulis dalam menyelesaikan jurnal ini. Kemudian penulis juga mengucapkan terima kasih kepada STKIP Singkawang yang telah memfasilitasi penulis dalam menyelesaikan jurnal ini.

\section{DAFTAR PUSTAKA}

[1] NCTM.Principles and Standards for School Mathematics. Reston: United States of America. 2000.

[2] Ipil."Penerapan Pendekatan Open-Ended dalam Pembelajaran Matematika untuk Meningkatkan Kemampuan Berpikir Kritis Siswa Ditinjau dari Respon Siswa Kelas X SMA". Jurnal Pasca Sarjana Pendidikan Matematika STKIP Sukoharjo: tidak Diterbitkan. 2012.

[3] Susanti. Pengaruh Model Pembelajaran Kooperatif Tipe Make A Match Terhadap Hasil Belajar Siswa Pada Materi Pertidaksamaan Linear Satu Variabel Di Kelas VII Nurul Islam. Skripsi STKIP PGRI Pontianak tidak diterbitkan. 2013.

[4] Hamdani. Strategi Belajar Mengajar. Bandung : Pustaka Setia. 2011.

[5] Huda, Miftahul. Model-Model Pengajaran dan Pembelajaran.Yogyakarta: Pustaka Pelajar. 2014

[6] Wahyuni. "Penggunaan penerapan pendekatan Open-Ended dapat meningkatkan pembelajaran matematika"Jurnal Pasca Sarjana Pendidikan Matematika STKIP Siliwangi, Bandung: Tidak Diterbitkan. 2013. 